\title{
A simple and efficient Agrobacterium- mediated in planta transformation protocol for horse gram (Macrotyloma uniflorum Lam. Verdc.)
}

Thomas Cheeran Amal ${ }^{1}$, Palanisamy Karthika ${ }^{1}$, Gurusamy Dhandapani ${ }^{2}$, Subramaniam Selvakumar ${ }^{3}$ and Krishnan Vasanth ${ }^{1 *}$

\begin{abstract}
Background: Recalcitrant nature is a major constraint for the in vitro regeneration and genetic transformation of leguminous species members. Therefore, an improved genetic transformation in horse gram has been developed via in planta method, in which Agrobacterium strain harboring binary vector pCAMBIA2301 was used for the transformation. Several factors affecting in planta transformations were put forth viz. Agrobacterium cell density, cocultivation, and sonication combined with vacuum infiltration duration which were optimized.

Results: Germinated seeds were sonicated and vacuum infiltrated with different densities of Agrobacterium culture and co-cultivated in half-strength MS medium with $100 \mu \mathrm{M}$ of acetosyringone for $48 \mathrm{~h}$. Seedlings were washed with cefotaxime and sowed in vermiculite soil for maturation. $T_{1}$ plants were subjected to histochemical and molecular analysis to ensure transformation efficiency. Among various combinations analyzed, maximum transformation efficiency (20.8\%) was attained with seeds of 5 min sonication combined with vacuum infiltration with 0.6 optical density of Agrobacterium culture.

Conclusions: It concludes that a different Agrobacterium cell density with sonication combined with vacuum infiltration has improved transgenic efficiency in horse gram plants. This simple and efficient method is feasible for the stable expression of foreign genes that could be beneficial for future food security.
\end{abstract}

Keywords: Horse gram, In planta transformation, Optical cell density, Sonication, Vacuum infiltration, GUS expression

\section{Background}

Horse gram (Macrotyloma uniflorum Lam. Verdc.) belongs to the family member of Fabaceae, widely used as a food crop particularly in Asian countries like Sri Lanka, Burma, and India [1]. In India, it is mainly cultivated in dryland areas of 3.25 lakh hectares that accounts for over 90\% in Tamil Nadu and Andhra Pradesh state [2], although it is susceptible to numerous biotic and abiotic

\footnotetext{
* Correspondence: vasanthlabbu@gmail.com

${ }^{1}$ Molecular Biology Laboratory, Department of Botany, School of Life Sciences, Bharathiar University, Coimbatore, Tamil Nadu 641046, India Full list of author information is available at the end of the article
}

factors such as yellow mosaic disease, anthracnose, leaf spot, rust and root rot [3-5]. The high drought-resistant characteristic makes an ideal choice for its cultivation under various climatic and edaphic conditions which provides a possible food source for the future. The less expensive source for higher protein, carbohydrate, and fiber content with lower levels of lipids makes a better choice for the developing countries [6-8]. It also has a good source of minerals and vitamins that help in weight reduction $[9,10]$. Apart from its various nutraceutical properties, it gives a potential remedy for various 
treatments like antihyperglycemia, antiobesity, and cardiovascular diseases [11-13].

The estimated genome size of $400 \mathrm{Mb}$ evolved in the active adaption and basal response against diseases and pest resistance, and it makes as an agriculturally attractive crop $[14,15]$. There are several conventional breeding methods adopted to develop hybrid varieties with disease and pest resistance. Significant success was achieved in the transformation of forage and pasture legumes via Agrobacterium-mediated transformation, which is the most popular and efficient method of plant genetic engineering [16-19]. In this study, the "in planta" transformation method was studied, where Agrobacterium is used to infect the seedlings. This method is simple and easy to perform in less time and does not require any skilled labor. Apart from that, several new strategies have been applied via agroinfiltration, sonication, vacuum infiltration, and floral dip methods which are now gaining much importance. Recently, several reports on the in planta transformation methods are emerging more than in vitro culture techniques [20-23].

Previous reports reveal inadequate information regarding the transformation in horse gram. Hence, the present research work has been carried out to produce the transgenic horse gram by in planta method optimized with different Agrobacterium optical cell densities and sonication combined with vacuum infiltration.

\section{Methods}

\section{Collection of seeds and sterilization}

Seeds of horse gram var. Paiyur 1 and Paiyur 2 were purchased from Regional Research Station, Paiyur, Tamil $\mathrm{Nadu}$, India. Initially, the seeds were washed with Tween 20 solution for $5 \mathrm{~min}$ and rinsed using running tap water. Surface sterilization was done with $4 \%$ sodium hypochlorite for $5 \mathrm{~min}$, followed by $70 \%$ ethanol washes for $2 \mathrm{~min}$. Further, the seeds were properly washed thrice in sterile double-distilled water followed by surface sterilization with $0.1 \% \mathrm{HgCl}_{2}(\mathrm{w} / \mathrm{v})$ for $5 \mathrm{~min}$. Finally, the seeds were thoroughly washed for five to six times in sterile water and germinated on Whatman filter papers.

\section{Analysis of seed germination percentage}

Seed germination refers to the initial appearance of radicle length, and nearly $2 \mathrm{~mm}$ was measured. To determine the germination percentage, healthy seeds were selected and placed in Petri plates with moistened Whatman filter papers in dark conditions at $25 \pm 2{ }^{\circ} \mathrm{C}$. Germination rate was counted every day (up to the 7 th day). Germination percentage was calculated by using the following formula:

$$
\text { Germination percentage }=\frac{\text { number of seeds germinated }}{\text { total number of seeds }} \times 100
$$

Gene, strain, binary vector, and Agrobacterium culture For transformation studies, Agrobacterium tumefaciens strain EHA105 harboring the binary vector pCAMBIA2301 was used. The T-DNA region carries uidA or GUS $-A$ reporter gene and was initiated by CaMV35S promoter and NOS terminator sequences, and the kanamycin-resistant gene, NPTII, was governed by the CaMV35S promoter and terminator sequences (Fig. 1). A loop of a colony from the mother culture was inoculated in a $50 \mathrm{~mL}$ of yeast extract mannitol (YEM) medium supplemented with kanamycin $50 \mathrm{mg} / \mathrm{L}$ and rifampicin $20 \mathrm{mg} / \mathrm{L}$ for $16-18 \mathrm{~h}$ at $28^{\circ} \mathrm{C}$ with $180 \mathrm{rpm}$. The cells of $200 \mu \mathrm{L}$ culture at $\log$ phase were taken and added into a fresh 100-mL medium containing the above antibiotics at $28{ }^{\circ} \mathrm{C}$. Afterwards, the Agrobacterium culture with various cell densities of $0,0.3,0.6$, and $0.8 \mathrm{OD}$ was harvested by centrifugation at $8000 \mathrm{rpm}$ for $10 \mathrm{~min}$. The supernatants were discarded and the resulting pellet was dissolved in an infiltration medium comprising 3 mM MES, $1 / 2$ strength MS medium supplemented with $3 \%$ sucrose, and $100 \mu \mathrm{M}$ acetosyringone (final pH 5.4).

\section{In planta transformation}

The horse gram, var. Paiyur 2, was used to study the in planta transformation efficiency. Several factors were optimized such as Agrobacterium cell density, infection time, and sonication combined vacuum infiltration. Initially, seeds were surface-sterilized and germinated for $24 \mathrm{~h}$ in dark condition on sterilized moistened paper towels in Petri dishes at $25^{\circ} \mathrm{C}$. (Fig. 2a). Plumules of 1 $\mathrm{cm}$ in length devoid of seed coats were used for transformation. Agrobacterium cells were inoculated in the YEM liquid medium with respective antibiotics and cultured overnight at $28^{\circ} \mathrm{C}$ with $180 \mathrm{rpm}$. Agrobacterium cells were harvested at different cell densities and resuspended in a 50-mL infiltration medium containing $100 \mu \mathrm{M}$ acetosyringone.

The seeds were gently pricked two to three times using a sterile needle and immediately transferred into the Agrobacterium infiltration medium at different time $(0,10,15$, and $30 \mathrm{~min}$ ) intervals followed by sonication for $0,2.5,5.0$, and $7.5 \mathrm{~min}$ (temperature $27^{\circ} \mathrm{C} ; 8 \mathrm{~s}$ on, $2 \mathrm{~s}$ off; $17 \%$ power) by using an ultrasonic homogenizer (SKL-150 DN model, frequency $45 \mathrm{kHz}$ ). Further, sonicated seeds were placed in a desiccator and vacuum infiltrated for $0,2.5,5.0$, and $7.5 \mathrm{~min}(300 \mathrm{mmHg})$ using a vacuum pump instrument (GAST DOA-P704-AA). Subsequently, seeds were blotted on a sterile filter paper for $15 \mathrm{~min}$ for the removal of excess Agrobacterium cells. The seeds were further transferred to Petri dishes for co-cultivation in the dark at 25 


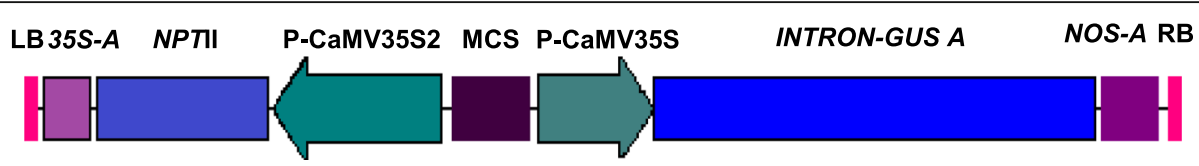

Fig. 1 T-DNA regions of binary vector PCAMBIA2301 used for the in planta transformation have the NPTI gene as plant selectable marker in the left border (LB) driven by CaMV35S2 promoter and CaMV35S terminator and Intron-GUS A as a reporter gene in the right border (RB) driven by CaMV35S promoter and NOS-terminator

${ }^{\circ} \mathrm{C}$ for $48 \mathrm{~h}$. The co-cultivated seeds have been rinsed thrice in sterile double-distilled water supplemented with $250 \mathrm{mg} / \mathrm{L}$ of cefotaxime to remove Agrobacterium contamination. The seedlings were transferred to the pots containing autoclaved vermiculite soil for further germination and maturity (Fig. 2b-f) whereas the seeds without Agroinfection were used as control. The seeds were collected from agroinfected $T_{0}$ plants and germinated on the half-strength MS medium supplemented with $100 \mathrm{mg} / \mathrm{L}$ kanamycin for the screening of putative transgenic plants. Subsequently, the $T_{1}$ plants were used for the GUS histochemical staining assay and molecular confirmation.

\section{GUS histochemical analysis for stable gene expression}

This method was carried out to analyze the stable GUS gene expression in $T_{1}$ germinated seedlings and leaf samples according to the described procedure [24]. Initially, the seedlings and leaf samples were washed in 50 $\mathrm{mM}$ sodium phosphate buffer ( $\mathrm{pH} 7.0)$ and incubated in a GUS histochemical reagent (50 $\mathrm{mM}$ sodium phosphate buffer (pH 7.0), $\quad 0.5 \mathrm{M} \quad$ EDTA $\quad(\mathrm{pH} 7.0), \quad 100 \mathrm{mM}$ $\mathrm{K} 3[\mathrm{Fe}(\mathrm{CN}) 6], 100 \mathrm{mM} \mathrm{K} 4[\mathrm{Fe}(\mathrm{CN}) 6], 1 \%$ Triton X-100) for $30-45 \mathrm{~min}$ at $37{ }^{\circ} \mathrm{C}$. Afterwards, the samples were transferred into a X-gluc staining solution $(2 \mathrm{mM} \mathrm{X}$ gluc, $50 \mathrm{mM}$ sodium phosphate buffer, $20 \%$ methanol)
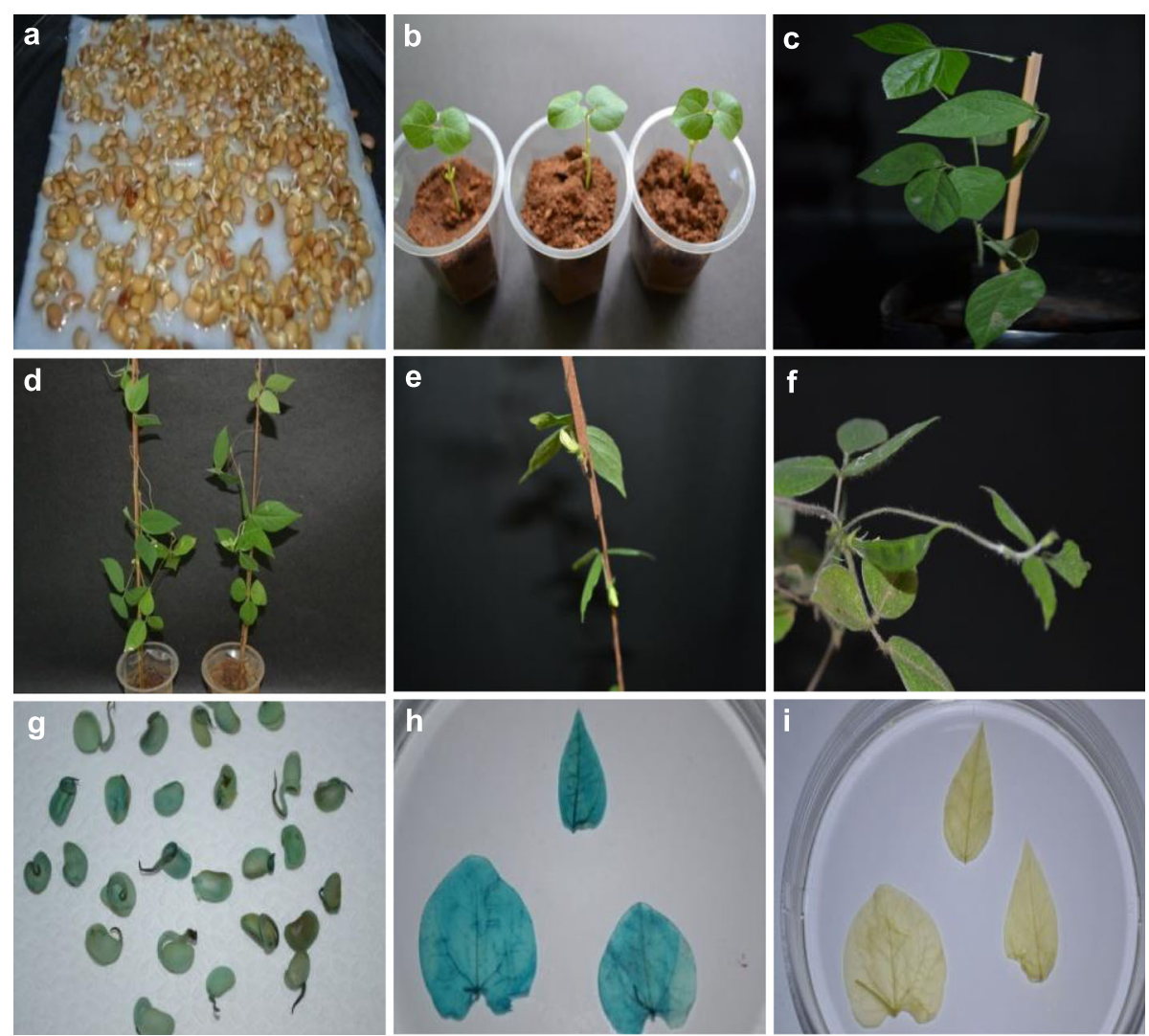

Fig. 2 In planta Agrobacterium-mediated genetic transformation of horse gram (var. Paiyur 2). a Germinated horse gram seeds used for the infection of Agrobacterium tumefaciens strain. b 7-day-old acclimatized putatively transformed plant. c 14-day-old acclimatized putatively transformed plant. d 50-day-old acclimatized putatively transformed plant by seedlings co-cultivated with Agrobacterium tumefaciens strain EHA105 harboring PCAMBIA2301 binary plasmid. e Putatively transformed plants shows the flowering. f Pod formation at 55 days. $\mathbf{g}$ GUS histochemical staining was performed in $T_{1}$ horse gram seedlings. $\mathbf{h}$ Leaves show GUS expression. i Non-transferred (control) plant leaves show no GUS expression at all 
and placed in dark condition for $24-48 \mathrm{~h}$ at $37{ }^{\circ} \mathrm{C}$. After incubation, the chlorophyll pigments were completely destained with $100 \%$ ethanol and the samples were observed for the GUS expression.

\section{Isolation of plant genomic DNA and PCR analysis}

Plant genomic DNA was isolated from leaf samples of selected $T_{1}$ GUS-positive and wild-type control plants using a modified cetyltrimethylammonium bromide (CTAB) method [25]. Polymerase chain reaction (PCR) was executed to find the presence and integration of both GUS and NPTII gene fragments using genomic DNA isolated from $T_{1}$ transgenic and non-transgenic (negative control) leaf samples along with plasmid pCAMBIA2301 control (positive control). The standard PCR procedure was followed using primers specific to the NPTII gene (FP: 5'-TCAGAAGAACTCGTCAAGAAGGCGATA-3'; RP: 5' -GGGGATTGAACAAG ATGGATTGCACGC-3') and GUS gene (FP: 5'TTATGCGGGCAACGTCTGGTATCA-3'; RP: 5' ACGCTTGGGTGGTTTTTGTCA-3'). The amplification of respective genes was performed in a PCR thermal cycler-200 ${ }^{\mathrm{TM}}$ (MJ Research Inc., Waltham, Mass, USA). The PCR conditions were programmed with $94{ }^{\circ} \mathrm{C}$ for 5 min of initial denaturation, repeated for 32 cycles at 94 ${ }^{\circ} \mathrm{C}$ for $1 \mathrm{~min}$ of denaturation, $60{ }^{\circ} \mathrm{C}$ for $1 \mathrm{~min}$ of annealing, and $72{ }^{\circ} \mathrm{C}$ for $1 \mathrm{~min}$ of extension, followed by $72{ }^{\circ} \mathrm{C}$ for $10 \mathrm{~min}$ of final extension. Finally, the amplified PCR fragments were confirmed qualitatively by electrophoresis in $0.8 \%$ agarose gel and gel image captured using a Syngene gel documentation system (G-Box).

Total RNA isolation and semi-quantitative RT-PCR analysis Total RNA was extracted from GUS and genomic PCRpositive transgenic and wild-type control plants by using spectrum $^{\text {TM }}$ plant total RNA isolation kit (Sigma-Aldrich, USA). Semi-quantitative reverse transcriptase polymerase chain reaction (RT-PCR) was performed to study the stable gene expression of NPTII and GUS transcripts. One microgram of total RNA was reversetranscribed to single-stranded cDNA using AffinityScript QPCR cDNA Synthesis Kit according to the manufacturer's guidelines (Stratagene, USA). PCR cycling parameters were set as initial denaturation of $94{ }^{\circ} \mathrm{C}$ for $3 \mathrm{~min}$, repeated by 30 cycles of $94{ }^{\circ} \mathrm{C}$ for $40 \mathrm{~s}, 60{ }^{\circ} \mathrm{C}$ for $40 \mathrm{~s}$, and $72{ }^{\circ} \mathrm{C}$ for $60 \mathrm{~s}$, and a final extension at $72{ }^{\circ} \mathrm{C}$ for 10 min. Amplified fragments were analyzed by $0.8 \%$ agarose gel electrophoresis and then visualized using Syngene gel documentation system (G-Box).

\section{Statistical analysis}

The data were analyzed using SPSS software (Version 17.0, SPSS Inc, USA). The experiments were performed thrice and subjected to one-way analysis of variance
(ANOVA) followed by Duncan's multiple range test (DMRT) at $P<0.05$ significance level.

\section{Results}

The present study describes a rapid and efficient protocol for the development of transgenic horse gram as an alternative for tissue culture method (Fig. 3).

\section{Assessment of seed germination percentage}

The determination of seed germination percentage provides importance for the in planta transformation to obtain maximum transgenic plants. The seeds of both Paiyur 1 and Paiyur 2 variety showed 87 and 93\% germination, respectively. Among these two varieties, Paiyur 2 exhibited maximum germination percentage (93\%). Therefore, further studies were carried out in the Paiyur 2 variety to assess different parameters influencing the in planta method.

\section{Agrobacterium cell density on survival rate and transgenic efficiency}

Agrobacterium optical cell density and infection time plays a significant role in the in planta Agrobacteriummediated transformation. Survivability index was the crucial parameter to achieve the maximum number of transgenic plants. Correspondingly, different growth phases of Agrobacterium (0, 0.3, 0.6, and 0.8 OD) culture

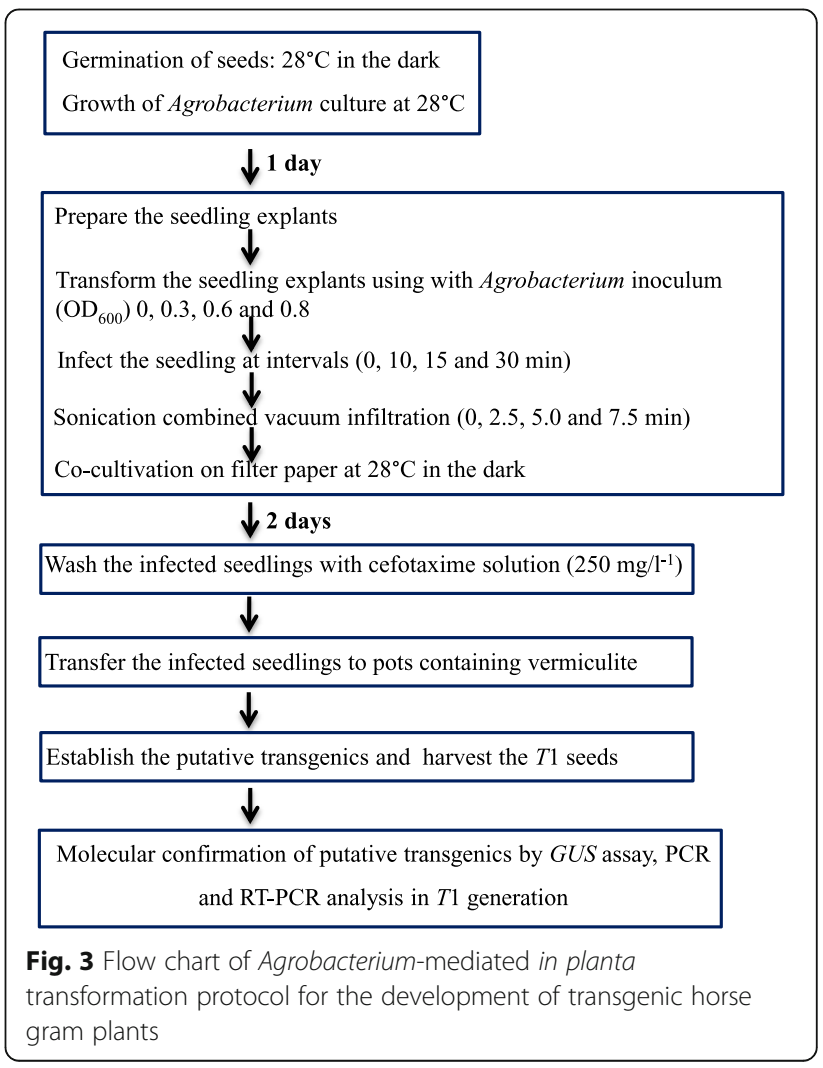


with different infection periods $(0,10,15$, and $30 \mathrm{~min})$ were tested to obtain the maximum plants' survival. Among different combinations tested, the maximum percent of plant survivability (83.3\%) was obtained at 0.3 OD with $10 \mathrm{~min}$ of infection period whereas the least survival (40\%) was recorded at $0.8 \mathrm{OD}$ with $30 \mathrm{~min}$ of infection period (Fig. 4a). Among various Agrobacterium cell density and infection times tested, seeds were subjected to 0.6 OD with 15 min infection time resulted in improved transformation efficiency of $8.1 \%$ (Table 1 ). Further, 0.8 OD with 30 min infection time has resulted in a significant reduction in transformation efficiency.

Influence of sonication combined with vacuum infiltration on transgenic efficiency

To pinpoint the efficient methods for transformation, different Agrobacterium cell densities (0, 0.3, 0.6, and 0.8 OD) with different time intervals of sonication and vacuum infiltration $(0,2.5,5.0$, and $7.5 \mathrm{~min})$ were recorded. Among different combinations tested, the highest transformation efficiency (20.8\%) was obtained when seeds were subjected 5 min of sonication and vacuum infiltration with 0.6 optical density of Agrobacterium culture. However, sonication and vacuum infiltration beyond $5 \mathrm{~min}$ has reduced the transformation efficiency (Table 2 and Fig. 4b). Similarly, transgenic recovery was also decreased while increasing the cell density. The effect of sonication and vacuum infiltration has many disadvantages on the survival rate of germination; however, putative transgenic efficiency of the combination was the maximum.

\section{GUS histochemical analysis of putative transgenics}

GUS histochemical assay was used to analyze the GUS gene expression in putative transgenic horse gram plants. The assay was performed in $T_{1}$ leaves and

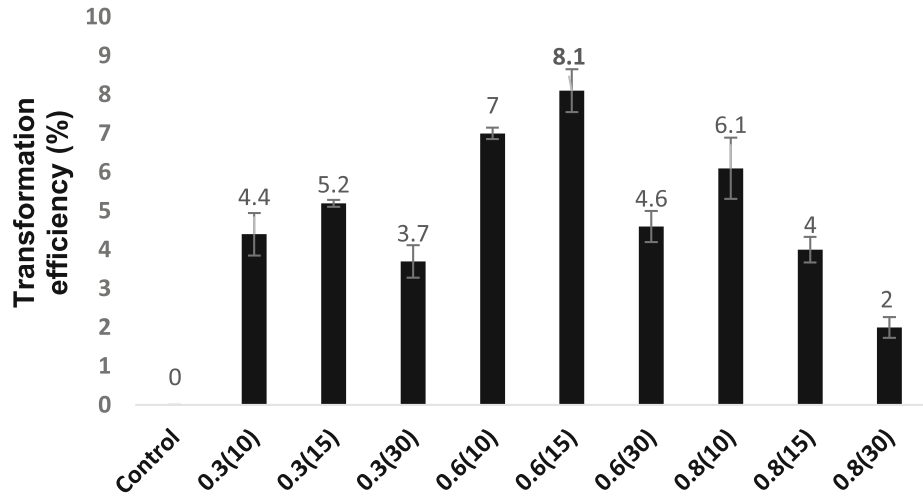

Agrobacterium cell density (infection time)

b

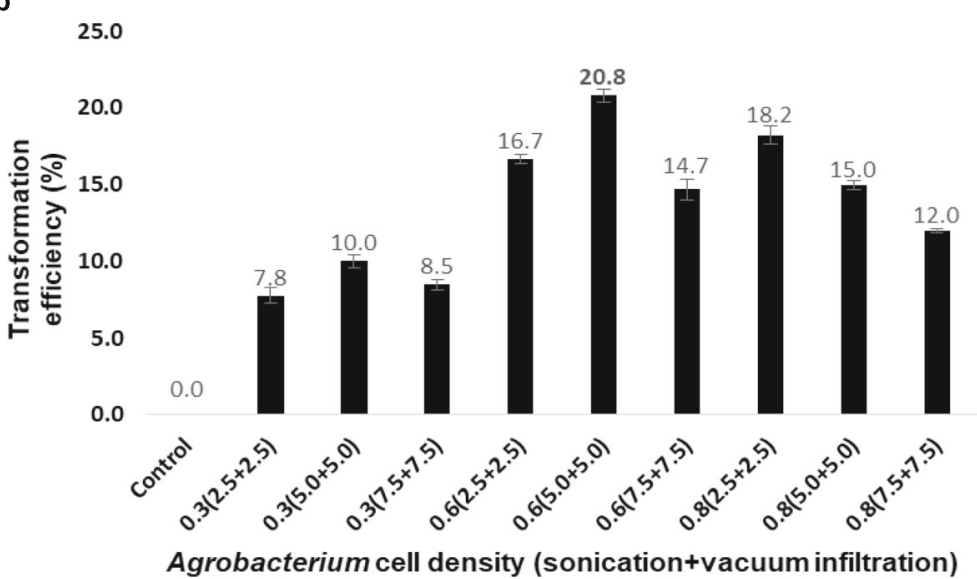

Fig. 4 Effect of Agrobacterium optical cell density, infection period, and sonication combined with vacuum infiltration on influencing the in planta transformation of horse gram. a Effect of Agrobacterium cell density and infection time on transformation efficiency. $\mathbf{b}$ Effect of Agrobacterium cell density and sonication combined with vacuum infiltration on influencing the in planta transformation efficiency 
Table 1 Effects of different Agrobacterium culture densities and infection period on the survival rate and gus A gene expression in horse gram plants

\begin{tabular}{lllll}
\hline $\begin{array}{l}\text { Agrobacterium optical } \\
\text { cell density (OD) }\end{array}$ & Infection time (min) & No. of seeds infected & $\begin{array}{l}\text { Mean no. of survived } \\
\text { plants (\%) }\end{array}$ & $\begin{array}{l}\text { Mean no. of plants expressing } \\
\text { gus A gene }\end{array}$ \\
\hline Control & 0 & 100 & $93.33 \pm 0.72^{\mathrm{a}}$ & $0 \pm 0^{f}$ \\
0.3 & 100 & 100 & $83.33 \pm 0.42^{\mathrm{b}}$ & $4.4 \pm 0.55^{\mathrm{d}}$ \\
& 10 & 100 & $73.67 \pm 1.14^{\mathrm{d}}$ & $5.2 \pm 0.09^{\mathrm{cd}}$ \\
& 15 & 100 & $60.67 \pm 0.56^{\mathrm{f}}$ & $3.7 \pm 0.42^{\mathrm{d}}$ \\
0.6 & 100 & 100 & $81.33 \pm 0.67^{\mathrm{bc}}$ & $7.0 \pm 0.15^{\mathrm{ab}}$ \\
& 10 & 100 & $78.33 \pm 0.83^{\mathrm{c}}$ & $4.1 \pm 0.55^{\mathrm{a}}$ \\
0.8 & 15 & 100 & $70.00 \pm 0.77^{\mathrm{de}}$ & $6.40^{\mathrm{cd}}$ \\
& 30 & 100 & $66.33 \pm 0.79^{\mathrm{e}}$ & $6.1 \pm 0.79^{\mathrm{bc}}$ \\
& 10 & $50.00 \pm 0.77^{\mathrm{g}}$ & $4.0 \pm 0.33^{\mathrm{d}}$
\end{tabular}

Mean values of three separate trials $( \pm$ ) with standard errors. In each column, numbers with different letters indicate they are considerably different from each other according to Duncan's multiple range test at a probability level of $5 \%$

seedlings of putative transformed and control plants. An intense blue color formation was observed in the transgenic seedlings and leaf samples (Fig. 2g, h). Samples devoid by the blue color were the non-transgenics (Fig. 2i). The degree of GUS expression was not uniform in all transgenic lines analyzed.

\section{Molecular analysis of transgenic horse gram}

The presence and expression of the transgene in transgenic horse gram plants were confirmed by genomic PCR and semi-quantitative RT-PCR analysis, respectively. Genomic DNA from nine GUS-positive transgenic $(\mathrm{H} 1, \mathrm{H} 2, \mathrm{H} 3, \mathrm{H} 4, \mathrm{H} 5, \mathrm{H} 6, \mathrm{H} 7, \mathrm{H} 8$, and H9) and non-transformed control (WT) plants were isolated and PCR was performed using NPTII- and GUS-specific primers. The PCR yielded an amplicon size of $796 \mathrm{bp}$ and $1.0 \mathrm{~kb}$ of the NPTII (Fig. 5a) and GUS gene (Fig. 5b) fragments, respectively, in all GUS-positive transgenic lines and also in DNA from plasmid control were used as a positive control, whereas amplification fragments were absent in a non-trangenic wild-type control (WT) plant which was used as a negative control (Fig. 5a, b).

To analyze the expression of the transgene, semiquantitative RT-PCR analysis was performed in nine $(\mathrm{H} 1$, H2, H3, H4, H5, H6, H7, H8, and H9) GUS- and PCRpositive plants. The RT-PCR yielded a fragment of $796 \mathrm{bp}$ and $1.0 \mathrm{~kb}$ of the NPTII (Fig. 5c) and GUS (Fig. 5d) transcript, respectively, in all transgenic lines and also in plasmid control which was used as positive control and absent in a non-trangenic control (WT) plant which was used as negative control (Fig. 5c, d).

Table 2 Effects of different Agrobacterium culture densities and duration of sonication + vacuum infiltration on the survival rate and gus A gene expression in horse gram

\begin{tabular}{lllll}
\hline $\begin{array}{l}\text { Agrobacterium cell } \\
\text { density (OD) }\end{array}$ & Sonication + vacuum (min) & No. of infected seeds & $\begin{array}{l}\text { Mean no. of survived } \\
\text { plants (\%) }\end{array}$ & $\begin{array}{l}\text { Mean no. of plants expressing } \\
\text { gus A gene }\end{array}$ \\
\hline Control & 0 & 100 & $94.00 \pm 0.58^{\mathrm{a}}$ & $0 \pm 0^{\mathrm{h}}$ \\
0.3 & 100 & $87.33 \pm 0.56^{\mathrm{b}}$ & $7.8 \pm 0.51^{\mathrm{g}}$ \\
& $2.5+2.5$ & 100 & $82.67 \pm 0.76^{\mathrm{cd}}$ & $10.0 \pm 0.42^{\mathrm{f}}$ \\
& $5.0+5.0$ & 100 & $68.33 \pm 0.95^{\mathrm{ef}}$ & $8.5 \pm 0.32^{\mathrm{g}}$ \\
0.6 & 100 & 100 & $85.00 \pm 0.76^{\mathrm{bc}}$ & $16.7 \pm 0.31^{\mathrm{c}}$ \\
& $7.5+7.5$ & 100 & $80.00 \pm 0.52^{\mathrm{d}}$ & $20.8 \pm 0.40^{\mathrm{a}}$ \\
0.8 & 100 & $72.33 \pm 0.70^{\mathrm{e}}$ & $14.7 \pm 0.69^{\mathrm{d}}$ \\
& $5.5+2.5$ & 100 & $70.00 \pm 0.82^{\mathrm{ef}}$ & $18.2 \pm 0.61^{\mathrm{b}}$ \\
& $7.5+7.5$ & 100 & $65.67 \pm 0.75^{\mathrm{f}}$ & $15.0 \pm 0.27^{\mathrm{d}}$ \\
\hline
\end{tabular}

Mean values of three separate trials ( \pm ) with standard errors. In each column, numbers with different letters indicate they are considerably different from each other according to Duncan's multiple range test at a probability level of $5 \%$ 


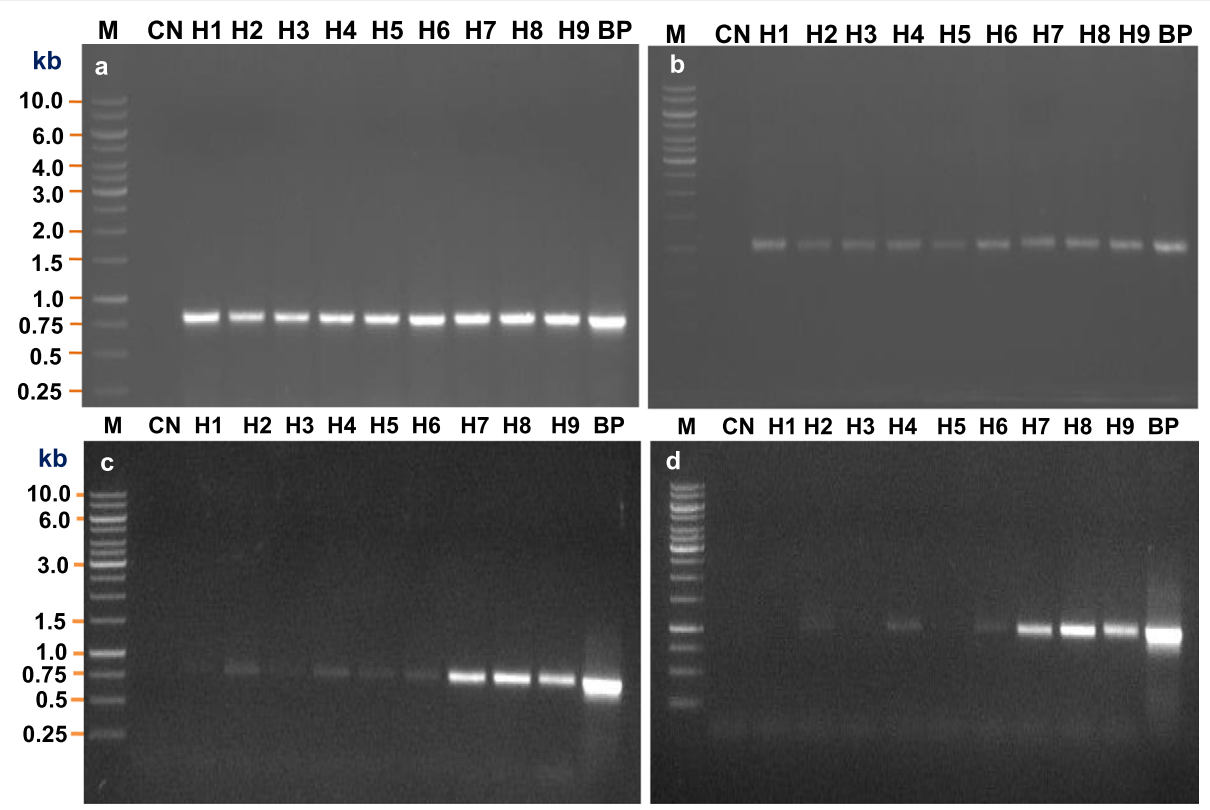

Fig. 5 Molecular analysis of in planta $T_{1}$ transgenic horse gram plants. $\mathbf{a}, \mathbf{b}$ Genomic DNA was isolated from control (CN) and nine putative $T_{1}$ transgenic horse gram leaf samples and the PCR analysis performed using NPTII (a) and GUS (b) gene-specific primers, respectively. c, d RT-PCR analysis of transgenic horse gram plants using NPTII c and GUS $\mathbf{d}$ gene-specific primers, respectively. Total RNA was isolated from control and putative transgenic lines and then converted to the single-stranded CDNA and performed the RT-PCR to study the expression of NPTI and GUS transcript. Note: 796 bp and $1.0 \mathrm{~kb}$ PCR products were observed in all transgenic plants except control (CN) using NPTII and GUS gene-specific primer, respectively. M $1.0 \mathrm{~kb}$ DNA ladder (Fermentas, Thermo Scientific), CN control plant, H1-H9 different transgenic lines, BP E. coli binary plasmid PCAMBIA2301

\section{Discussion}

The agricultural revolution has been happening predominantly due to the remarkable nature of seeds for its convenient storage and fast propagation and makes it ideal for human requirements. Horse gram is one of the prehistoric pulse crops from the time when agriculture particularly started in South Asia [2, 26]. Among different pulse crops, the cultivation and exploration of this crop become limited due to wild dormancy and various biotic factors. In this study, a simple and effective in planta Agrobacterium-mediated transformation method for the development of transgenic horse gram has been reported. Here, seeds were used as an explant for the transformation because of its fast-multiplying cells during germination which is useful for the integration of the target gene. The seed germination percentage was best in Paiyur 2 variety compared to Paiyur 1 . The thick and hard seed coats of horse gram is one of the major drawbacks for the efficient uptake of foreign DNA into the plant genome, even though numerous methods can be adopted for the efficient recovery of transgenic plants. There are several recent reports on the seeds as explants for the in planta transformation [27-30].

Selection of appropriate strain and cell density are the prerequisites for transformation in dicot species. In several leguminous members, the Agrobacterium EHA105 strain was found the best choice for the transformation recovery and stable integration of genes [31-33]. Based on our investigation, an Agrobacterium cell density of 0.6 OD produced the highest number of GUS positive in both sonication combined vacuum treatment. However, the percentage of survival rate was gradually decreased in proportional to cell density and infection time. We found that some plants underwent necrosis and death, while the duration of infection and the cell density becomes increased. Similarly, infection time $>10$ min contributed to Agrobacterium resulted in overgrowth and $>35 \mathrm{~min}$ resulted in the browning of the target tissue. Correspondingly, nominal cell density with increased co-cultivation duration has the lowest stress response with maximum survivability of explants [21, 34, 35]. On the contrary, herbicide-resistant wheat and cotton plants raised by in planta method resulted in a maximum survival rate with $3.07 \%$ and $0.12 \%$ transformation efficiency $[30,36]$.

Nowadays, sonication and vacuum infiltration are the most convenient and simple method adopted for the in planta transformation. Improvising the penetration of Agrobacterium cells into the plant genome by the influence of sonic waves and vacuum tends to increase the efficiency of gene transfer. The purpose of vacuum infiltration after sonication may offer an additional access point for Agrobacterium, making it easier to integrate the transformation for the tissues [37]. Soybean cotyledonary node explants subjected to $2 \mathrm{~min}$ of sonication 
followed by vacuum infiltration resulted in $18.6 \%$ transformation efficiency [38], whereas precultured peanut explants are subjected to $6 \mathrm{~min}$ of sonication and $3 \mathrm{~min}$ of vacuum infiltration in Agrobacterium suspension resulting in $31.3 \%$ transformation efficiency [28]. The combined effects of sonication and vacuum infiltration treatments had been reported to have increased transformation efficiency in kidney bean and persimmon [39, 40].

For precise screening of transgenic plants, the GUS reporter gene was used to evaluate the promoter function for the visualization of expressive patterns throughout the plant tissues $[41,42]$. In the present study, there was a high level of GUS expression observed in leaf materials than stem and seed explants. Correspondingly, blue color visualization was absent in control (non-transformed) plants. Different parameters like Agrobacterium cell density, sonication, vacuum infiltration, and cocultivation were influenced by the transformation efficiency and GUS expression in transgenic plants. This may be due to the integration, copy number, and expression of the transgene in plants $[43,44]$ or due to the methylation of the chromosomal integration region [45]. Finally, the stable expression and integration of desired genes were confirmed by PCR and semi-quantitative RT-PCR.

\section{Conclusions}

The present study demonstrated the development of transgenic horse gram by subjecting in planta transformation protocol. The results revealed that the percentage of survival rate was gradually decreased with increased Agrobacterium cell density and infection period. The combined effects of sonication and vacuum infiltration showed greater transgenic efficiency, but the lowest survival rate of germinating seeds was observed. Germinated seedlings of $24 \mathrm{~h}$ were used for the infection of Agrobacterium culture at 0.6 OD followed by 5 min of sonication and vacuum $(300 \mathrm{mmHg})$ infiltration followed by 2 days of co-cultivation resulted in $20.8 \%$ of the transgenic efficiency. Agrobacterium-mediated genetic transformation by in planta method in horse gram is the first report that states this kind. This protocol would be efficient and easier for genetic manipulation against several biotic factors and also helps to improve the nutritional quality of the pulse crop for human welfare.

\section{Abbreviations}

OD: Optical density; CaMV: Cauliflower mosaic virus;

CTAB: Cetyltrimethylammonium bromide; T-DNA: Transfer-DNA;

$\mathrm{HgCl}_{2}$ : Mercuric chloride; MES: 2-(N-morpholino)ethanesulfonic acid; GUS: $\beta-$ Glucuronidase; X-gluc: 5-Bromo-4-chloro-3-indolyl-beta-D-glucuronic acid;

EDTA: Ethylenediaminetetraacetic acid; NPTI: Neomycin phosphotransferase; RT-PCR: Reverse transcription polymerase chain reaction; ANOVA: Analysis of variance; DMRT: Duncan's multiple range test

\section{Acknowledgements}

We convey our thanks and acknowledge Dr. P. Ananda Kumar, ICAR-Indian Rice Research Institute, Hyderabad, for providing Agrobacterium tumefaciens strain EHA105 harboring the binary vector pCAMBIA2301. Also, we would like to thank the reviewers for their insightful comments and suggestions on the manuscript to improve the quality of the publication.

\section{Authors' contributions}

$K V, G D$, and TCA designed the work, analyzed the data, and wrote the manuscript. TCA and PK conducted the experiments. SS carried out RT-PCR studies and also reviewed and modified the final manuscript. The authors have read and approved the final manuscript.

\section{Funding}

The research was conducted with the financial support of the project No. SB/YS/LS-84/2014 from the Department of Science and Technology-Science and Engineering Research Board (DST-SERB), New Delhi. The funds were used to buy instruments and chemicals required for the project. The entire work was carried out in Bharathiar University, Coimbatore, 641046.

Availability of data and materials

Not applicable

Ethics approval and consent to participate

Not applicable

Consent for publication

Not applicable

\section{Competing interests}

The authors declare that they have no competing interests.

\section{Author details}

${ }^{1}$ Molecular Biology Laboratory, Department of Botany, School of Life Sciences, Bharathiar University, Coimbatore, Tamil Nadu 641046, India. ${ }^{2}$ PG Research Department of Botany, Kongunadu Arts and Science College, Bharathiar University, Coimbatore, Tamil Nadu 641029, India. ${ }^{3}$ Department of Biochemistry, School of Life Sciences, Bharathiar University, Coimbatore, Tamil Nadu 641046, India.

Received: 12 October 2019 Accepted: 2 March 2020

Published online: 24 March 2020

\section{References}

1. Duke JA (1981) Handbook of legumes of world economic importance. Springer US

2. Fuller DQ, Murphy C (2018) The origins and early dispersal of horse gram (Macrotyloma uniflorum), a major crop of ancient India. Genet Resour Crop Evol 65:285-305. https://doi.org/10.1007/s10722-017-0532-2

3. Williams FJ, Grewal JS, Amin KS (1968) Serious and new diseases of pulse crops in India in 1966. Plant Dis Rep 52:300-304

4. Muniyappa V, Rajeshwari R, Bharathan N, Reddy DVR, Nolt BL (1987) Isolation and characterization of a geminivirus causing yellow mosaic disease of horse gram (Macrotyloma uniflorum [Lam.] Verdc.) in India. J Phytopathol 119:81-87. https://doi.org/10.1111/j.1439-0434.1987.tb04386.x

5. Udayasankar A, Kamakshi N, Anitha K (2017) Incidence of Colletotrichum spp. on horse gram - a critical review. Int J Pure App Biosci 5:513-517. https:// doi.org/10.18782/2320-7051.5085

6. Singh U, Singh B (1992) Tropical grain legumes as important human foods. Econ Bot 46:310-321. https://doi.org/10.1007/BF02866630

7. Jacobs DR, Steffen LM (2003) Nutrients, foods, and dietary patterns as exposures in research: a framework for food synergy. Am J Clin Nutr 78: 508-513. https://doi.org/10.1093/ajcn/78.3.508S

8. Yadav S, Negi KS, Mandal S (2004) Protein and oil rich wild horse gram. Genet Resour Crop Evol 51:629-633. https://doi.org/10.1023/B:GRES. $0000024650.44318 .2 d$

9. Sreerama YN, Neelam DA, Sashikala VB, Pratape VM (2010) Distribution of nutrients and antinutrients in milled fractions of chickpea and horse gram: seed coat phenolics and their distinct modes of enzyme inhibition. J Agric Food Chem 58:4322-4330. https://doi.org/10.1021/jf903101k 
10. Kadam SS, Salunkhe DK (1985) Nutritional composition, processing, and utilization of horse gram and moth bean. Crit Rev Food Sci Nutr 22:1-26. https://doi.org/10.1080/10408398509527416

11. Daskaya-Dikmen C, Yucetepe A, Karbancioglu-Guler F, Daskaya H, Ozcelik B (2017) Angiotensin-i-converting enzyme (ACE)-inhibitory peptides from plants. Nutrients 9. https://doi.org/10.3390/nu9040316

12. Mohan M, Elyas KK (2018) Anti-hyperglycemic properties of a purified proteinaceous protease inhibitor from Macrotyloma uniflorum seeds. Curr Top Med Chem 18:2502-2510. https://doi.org/10.2174/ 1568026619666181220110038

13. Bharathi V, Rengarajan RL, Radhakrishnan R, Hashem A, Abd Allah EF, Alqarawi AA (2018) Effects of a medicinal plant Macrotyloma uniflorum (Lam.) Verdc. formulation (MUF) on obesity-associated oxidative stressinduced liver injury. Saudi J Biol Sci 25:1115-1121. https://doi.org/10.1016/j. sjbs.2018.03.010

14. Bhardwaj J, Chauhan R, Swarnkar MK, Chahota RK, Singh AK, Shankar R (2013) Comprehensive transcriptomic study on Horse gram (Macrotyloma uniflorum): de novo assembly, functional characterization and comparative analysis in relation to drought stress. BMC Genomics 14:647. https://doi.org/ 10.1186/1471-2164-14-647

15. Bhardwaj J, Yadav SK (2015) Drought stress tolerant horse gram for sustainable agriculture, p. 293-328. doi:https://doi.org/10.1007/978-3-319-09132-7-7.

16. Collado R, Bermúdez-Caraballoso I, García LR, Veitía N, Torres D, Romero C (2016) Epicotyl sections as targets for plant regeneration and transient transformation of common bean using Agrobacterium tumefaciens. In vitro Cell Dev-PI. 52:500-511. https://doi.org/10.1007/s11627-016-9769-2

17. Li S, Cong Y, Liu Y, Wang T, Shuai Q, Chen N (2017) Optimization of Agrobacterium-mediated transformation in soybean. Front Plant Sci. 8:246. https://doi.org/10.3389/fpls.2017.00246

18. Kimura M, Isobe S (2018) Small-molecule screening to increase Agrobacterium-mediated transformation efficiency in legumes. Methods $\mathrm{Mol}$ Biol. 1795:93-99. https://doi.org/10.1007/978-1-4939-7874-8_8

19. Zhao Q, Du Y, Wang H, Rogers HJ, Yu C, Liu W (2019) 5-Azacytidine promotes shoot regeneration during Agrobacterium-mediated soybean transformation. Plant Physiol Biochem. 141:40-50. https://doi.org/10.1016/j. plaphy.2019.05.014

20. Chen G, Zeng F, Wang J, Ye X, Zhu S, Yuan L (2019) Transgenic wucai (Brassica campestris L.) produced via Agrobacterium-mediated anther transformation in planta. Plant Cell Rep. 38:577-586. https://doi.org/10.1007/ s00299-019-02387-0

21. Mortensen S, Bernal-Franco D, Cole LF, Sathitloetsakun S, Cram EJ, LeeParsons CWT (2019) Easi transformation: an efficient transient expression method for analyzing gene function in Catharanthus roseus seedlings. Front Plant Sci 2019:10. https://doi.org/10.3389/fpls.2019.00755

22. Hu D, Bent AF, Hou X, Li Y (2019) Agrobacterium-mediated vacuum infiltration and floral dip transformation of rapid-cycling Brassica rapa. BMC Plant Biol:19. https://doi.org/10.1186/s12870-019-1843-6

23. Aminedi $R$, Dhatwalia D, Jain V, Bhattacharya R (2019) High efficiency in planta transformation of Indian mustard (Brassica juncea) based on spraying of floral buds. Plant Cell Tissue Organ Cult. https://doi.org/10.1007/s11240019-01618-2

24. Jefferson RA, Kavanagh TA, Bevan MW (1987) GUS fusions: betaglucuronidase as a sensitive and versatile gene fusion marker in higher plants. EMBO J. 6:3901-3907. https://doi.org/10.1002/j.1460-2075.1987. tb02730.x

25. Porebski S, Bailey LG, Baum BR (1997) Modification of a CTAB DNA extraction protocol for plants containing high polysaccharide and polyphenol components. Plant Mol Biol Report. 15:8-15. https://doi.org/10. 1007/BF02772108

26. Murphy C, Fuller DQ (2017) Seed coat thinning during horse gram (Macrotyloma uniflorum) domestication documented through synchrotron tomography of archaeological seeds. Sci Rep. 7. https://doi.org/10.1038/ s41598-017-05244-w

27. Pandey S, Patel MK, Mishra A, Jha B (2016) In planta transformed cumin (Cuminum cyminum L.) plants, overexpressing the SbNHX1 gene showed enhanced salt endurance. PLoS One 11. https://doi.org/10.1371/journal. pone.0159349

28. Karthik S, Pavan G, Sathish S, Siva R, Kumar PS, Manickavasagam M (2018) Genotype-independent and enhanced in planta Agrobacterium tumefaciensmediated genetic transformation of peanut [Arachis hypogaea (L.)]. 3 Biotech 8:202. https://doi.org/10.1007/s13205-018-1231-1
29. Ahmed T, Biswas S, Elias SM, Sazzadur Rahman M, Tuteja N, Seraj ZI (2018) In Planta transformation for conferring salt tolerance to a tissue-culture unresponsive indica rice (Oryza sativa L.) cultivar. Vitr Cell Dev Biol - Plant. 54:154-165. https://doi.org/10.1007/s11627-017-9870-1

30. Tarafdar A, Vishwakarma H, Gothandapani S, Bhati M, Biswas K, Prakash A (2019) A quick, easy and cost-effective in planta method to develop direct transformants in wheat. 3 Biotech 9:180. https://doi.org/10.1007/s13205-019-1708-6

31. Schroeder HE, Schotz AH, Wardley-Richardson T, Spencer D, Higgins TJV (1993) Transformation and regeneration of two cultivars of pea (Pisum sativum L.). Plant Physiol. 101:751-757. https://doi.org/10.1104/pp.101.3.751

32. Trieu AT, Harrison MJ (1996) Rapid transformation of Medicago truncatula: regeneration via shoot organogenesis. Plant Cell Rep. 16:6-11. https://doi. org/10.1007/BF01275439

33. Chetty VJ, Ceballos N, Garcia D, Narváez-Vásquez J, Lopez W, OrozcoCárdenas ML (2013) Evaluation of four Agrobacterium tumefaciens strains for the genetic transformation of tomato (Solanum lycopersicum L.) cultivar MicroTom. Plant Cell Rep. 32:239-247. https://doi.org/10.1007/s00299-012-1358-1

34. Saini R, Jaiwal PK (2007) Agrobacterium tumefaciens-mediated transformation of blackgram: an assessment of factors influencing the efficiency of uidA gene transfer. Biol Plant. 51:69-74. https://doi.org/10.1007/s10535-007-0014-z

35. Zhang Z, Finer JJ (n.d.) Low Agrobacterium tumefaciens inoculum levels and a long co-culture period lead to reduced plant defense responses and increase transgenic shoot production of sunflower (Helianthus annuus L.). In Vitro Cell Dev Biol Plant 52:354-366. https://doi.org/10.1007/s1 1627-016-9774-5

36. Fang GUOW, Wang KY, Wang N, Li J, Qiang LG, Hu LD (2018) Rapid and convenient transformation of cotton (Gossypium hirsutum L.) using in planta shoot apex via glyphosate selection. J Integr Agric. 17:2196-2203. https:// doi.org/10.1016/S2095-3119(17)61865-3

37. de Oliveira MLP, Febres VJ, Costa MGC, Moore GA, Otoni WC (2009) Highefficiency Agrobacterium-mediated transformation of citrus via sonication and vacuum infiltration. Plant Cell Rep. 28:387-395. https://doi.org/10.1007/ s00299-008-0646-2

38. Arun M, Subramanyam K, Mariashibu TS, Theboral J, Shivanandhan G, Manickavasagam M (2015) Application of sonication in combination with vacuum infiltration enhances the Agrobacterium-mediated genetic transformation in Indian soybean cultivars. Appl Biochem Biotechnol 2015; 175:2266-2287. doi:https://doi.org/10.1007/s12010-014-1360-x.

39. Liu Z, Park BJ, Kanno A, Kameya T (2005) The novel use of a combination of sonication and vacuum infiltration in Agrobacterium-mediated transformation of kidney bean (Phaseolus vulgaris L.) with lea gene. Mol Breed. 16:189-197. https://doi.org/10.1007/s11032-005-6616-2

40. Mo R, Yang S, Zhang Q, Xu L, Luo Z (2019) Vacuum infiltration enhances the Agrobacterium-mediated transient transformation for gene functional analysis in persimmon (Diospyros kaki Thunb.). Sci Hortic. 251:174-180. https://doi.org/10.1016/j.scienta.2019.03.002

41. De Ruijter NCA, Verhees J, Van Leeuwen W, Van Der Krol AR (2003) Evaluation and comparison of the GUS, LUC and GFP reporter system for gene expression studies in plants. Plant Biol 5:103-115. https://doi.org/10. 1055/s-2003-40722

42. Velten J, Pogson B, J CC-TP, 2008 undefined. Luciferase as a reporter of gene activity in plants. AcademiaEdu n.d.

43. Hobbs SL, Warkentin TD, DeLong CM (1993) Transgene copy number can be positively or negatively associated with transgene expression. Plant Mol Biol. 21:17-26. https://doi.org/10.1007/bf00039614

44. Tjokrokusumo D, Heinrich T, Wylie S, Potter R, McComb J (2000) Vacuum infiltration of Petunia hybrida pollen with Agrobacterium tumefaciens to achieve plant transformation. Plant Cell Rep. 19:792-797. https://doi.org/10. 1007/s002990050009

45. Pröls F, Meyer $P$ (1992) The methylation patterns of chromosomal integration regions influence gene activity of transferred DNA in Petunia hybrida. Plant J. 2:465-475. https://doi.org/10.1046/j.1365-313x.1992.t01-20-00999.x

\section{Publisher's Note}

Springer Nature remains neutral with regard to jurisdictional claims in published maps and institutional affiliations. 